\title{
EFFECTS OF HYDROPHILIC POLYMER ON THE SURVIVAL, GROWTH, AND FLOWERING CHARACTERISTICS OF PINEAPPLE SAGE (SALVIA ELEGANS) IN UNIRRIGATED GREEN ROOFS
}

\author{
JU, J. H. ${ }^{1}-$ XU, H. ${ }^{2}-$ YeUM, K. J. ${ }^{3}-$ YoON, Y. H. ${ }^{1 *}$ \\ ${ }^{1}$ Department of Green Convergence Technology, KonKuk University, 268 Chungwondaero, \\ Chungju, Chungcheongbuk-do 27478, South Korea
}

${ }^{2}$ College of Landscape Architecture, Central South University of Forestry and Technology, No. 498 Shaoshannanlu, Changsha 410004, China

${ }^{3}$ Division of Food Bioscience, College of Biomedical and Health Science, KonKuk University, 268 Chungwondaero, Chungju, Chungcheongbuk-do 27478, South Korea

*Corresponding author

e-mail: yonghan7204@kku.ac.kr; phone: +82-43-840-3538; fax: +82-43-851-4169

(Received $2^{\text {nd }}$ Oct 2019; accepted $19^{\text {th }}$ Mar 2020)

\begin{abstract}
This study aimed to determine the effects of different amounts of hydrophilic polymer, in three green roof substrates, on the growth of Salvia elegans. Coir dust and perlite were mixed in ratios of $80 \%$ to $20 \%\left(\mathrm{C}_{4} \mathrm{P}_{1}\right), 50 \%$ to $50 \%\left(\mathrm{C}_{1} \mathrm{P}_{1}\right)$, and 20 to $80 \%\left(\mathrm{C}_{1} \mathrm{P}_{4}\right)$ at a substrate depth of $20 \mathrm{~cm}$. Hydrophilic polymer were added to three substrates in the amounts of $0,0.25,0.5,1.0$, and $2.0 \mathrm{~kg} \cdot \mathrm{m}^{-3}$. The survival rate and visual quality of Salvia elegans were positively associated with hydrophilic polymer content in the three substrates. Although the growth of Salvia elegans was the greatest under the $\mathrm{C}_{4} \mathrm{P}_{1}$ substrate when measured in June (dry season), the greatest growth under the $\mathrm{C}_{1} \mathrm{P}_{4}$ substrate was in August (rainy season). Therefore, $\mathrm{C}_{4} \mathrm{P}_{1}$ and $\mathrm{C}_{1} \mathrm{P}_{1}$ substrates with high coir dust materials is not recommended for Salvia elegans because the plants showed low growth and chlorophyll contents in the rainy season and poor flowering with these substrates. Thus, perlite-based $\mathrm{C}_{1} \mathrm{P}_{4}$ amended with hydrophilic polymer at a level of $>1.0 \mathrm{~kg} \cdot \mathrm{m}^{-3}$ should be considered for the optimal substrate for Salvia elegans during droughts as well as rainy seasons on green roofs.
\end{abstract}

Keywords: hydrogels, ornamental herb, rainwater retention, inorganic amendment, urban agriculture

\section{Introduction}

Green roofs, also known as vegetated roofs, planted roofs, eco roofs, living roofs, or roof gardens, are roofs that are partially or completely covered with vegetation and substrate (Castleton et al., 2010). Because they provide environmental benefits, and open-air amenities without additional land acquisition costs, green roofs have become popular in many cities around the world (Getter et al., 2009). However, environmental conditions on rooftops are often extreme including high temperatures, strong winds, and long-term drought. An extensive green roof with a thin layer of substrate easily result in water deficit conditions (Young et al., 2017). Thus, extensive green roofs almost exclusively use vegetation such as herbs, grasses, mosses, and drought-tolerant succulents including sedum (Getter and Row, 2006). The composition and characteristics of green roof vegetation depends on many factors, growing substrate in particular (Krawczyk et al., 2017). To a large extent, substrate depth dictates vegetation diversity and the range of possible species (Oberndorfer et al., 2007). If growth media depth is limited and there is no additional irrigation, rainfall can restrict the use of 
certain species. Even though various organic components are effective in sustaining vegetation and increasing water retention (Xue and Farrell, 2020), high rates of organic matter $(>20 \%)$ can be problematic on green roofs due to rapid decomposition. It can lead to compaction, which reduces substrate depth, air supply for roots and water infiltration and retention (Handreck and Black, 2010) resulting in temporarily increased nutrient loads in stormwater runoff (Berndtsson, 2010). Therefore, to increase the use of green roofs, the utilization of inorganic amendments which can retain rainwater must be explored.

Hydrophilic polymers, also described as hydrogels or super absorbent polymers, are cross-linked crystalline forms of insoluble polyacrylamide gel that can keep water several hundred times heavier than that of theirs. The stored water in the hydrophilic polymers can be released to meet the needs of the plants. Therefore, they have been widely used to improve soil moisture in agriculture, horticulture, and forestry (Farrell et al., 2013). Many studies have demonstrated the effects of hydrophilic polymer amendment on plant growth. Barley (Hordeum vulgare L.), wheat (Triticum aestivum L.), and chickpea (Cicer arietinum L.) found that hydrogels delayed wilting time, improved soil water availability, and increased plant establishment (Akhter et al., 2004). Hydrogel amendment prolonged the survival of Picea abies, Pinus sylivestris, and Fagus sylvatica seedlings and improved their biomass under water stress (Orikiriza et al., 2013). Also, hydrogel amendment increased the survival of trees and reduced their evapotranspiration rates, Araucaria cunninghammi, and Maesopsis eminii (Hüttermann et al., 2009). Water retention gel and coarser particle size substrates can significantly improve the drought tolerance of green roof plants (Young et al., 2017). However, some studies have suggested that the volume of hydrophilic polymers has no effect on net photosynthesis, stomatal conductance, plant growth, or biomass. Meanwhile, Water retention gel and large brick substrates increased both Festuca ovina and Linaria vulgaris's drought tolerance while a Sedum living mulch had no effect (Apostol et al., 2009), there is need to examine various substrate compositions and characteristics as a valuable component of green roofs substrates, including hydrophilic polymer.

The genus Salvia is the largest genus in the Lamiaceae family, and contains more than 900 species worldwide (González-Cortazar et al., 2013). Because of its brilliant red flowers and pineapple-scented leaves, Salvia elegans is widely used in landscaping to attract butterflies and hummingbirds (Cuevas et al., 2018). This species need regular watering because of its sensitivity to drought and perish in deep frost (Silva et al., 2018). To the best of our knowledge, no studies have assessed the use of Salvia elegans on green roofs due to its sensitivity to drought. Therefore, the objectives of this study were to determine the effects of different amounts of hydrophilic polymer depending on three types of substrate on the growth of Salvia elegans on unirrigated agricultural green roofs.

\section{Materials and methods}

\section{Site description and experimental set up}

This experiment had a factorial design with three different substrates and five hydrophilic polymer treatments used. There were three replicates for each treatment and each replicate consisted of three plants. Although Salvia elegans is native to Mexico and grows in temperate climates (González-Cortazar et al., 2013), it can be frozen at a 
temperature lower than $-5^{\circ} \mathrm{C}$ (Park, 2007). Therefore, it is grown as an annual plant, which blooms until the first frost date in South Korea. For this reason, experimental period has been limited from May to November.

A total of 45 square plots $(50 \mathrm{~cm} \mathrm{[L]} \times 50 \mathrm{~cm} \mathrm{[W]} \times 25 \mathrm{~cm} \mathrm{[H]})$ were installed on a roof platform. From top to bottom, each square plot consisted of the following four layers: vegetation, substrate, geotextile filter, and drainage layer (Xu et al., 2014). A geotextile filter $(0.8 \mathrm{~mm}$ thick) with good air and water permeability was used to between substrate and drainage layer preventing the loss of substrate particles. Drainage layer was used to support the three layers above, restrict root growths, increase insulation, and retain excess water (Papafotiou et al., 2013).

All these plots were placed on the rooftop of KonKuk University, Chungju, South Korea located at latitude $35^{\circ} 49^{\prime} \mathrm{N}$ and longitude $127^{\circ} 08^{\prime} \mathrm{E}$ (Fig. 1). Monthly precipitation was $24.6,88.2,110.6,277.7,122.7,153.8$, and $23.5 \mathrm{~mm}$ in May, June, July, August, September, October, and November, respectively (Xu et al., 2014). These results showed reduced rainfall in June resulted in a severe drought period, while frequent rainfall were observed during the summer rainy season in August on the rooftop.

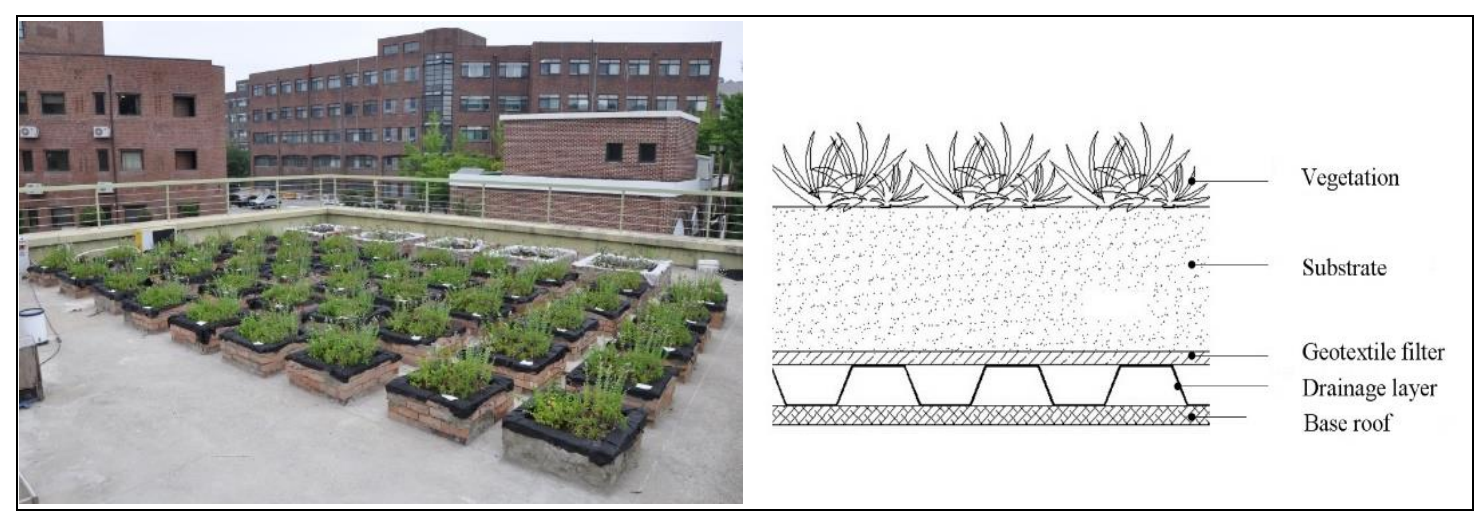

Figure 1. Field experimental study site (left) and sketch of cross section of the green roof (right)

\section{Experimental design and data analysis}

Seedlings of Salvia elegans were obtained from a commercial nursery. Three seedlings of Salvia elegans that had consistent plant height of $8 \mathrm{~cm}$ were transplanted into each green roof container on 14 May 2014. All plants were watered every 2 days in the first week after transplanting for seedling establishment, followed by no watering. In consideration of green roof substrate generally contains about $10-20 \%$ organic and 80-90\% inorgnic components (Rowe, 2011), experimental substrates were formulated with $20 \%, 50 \%$, or $80 \%$ (by volume) coir dust (Fibrosoil, Jayampathi Lanka Exports (Pvt) Ltd., Sri Lanka) and $80 \%, 50 \%$, or $20 \%$ (by volume) perlite (Pearl shine No.2, GFC. Co., Ltd., Korea). Coir dust and perlite were mixed in ratios of $80 \%$ to $20 \%$ $\left(\mathrm{C}_{4} \mathrm{P}_{1}\right), 50 \%$ to $50 \%\left(\mathrm{C}_{1} \mathrm{P}_{1}\right)$, and 20 to $80 \%\left(\mathrm{C}_{1} \mathrm{P}_{4}\right)$, respectively. Hydrophilic polymer (acrylic acid-sodium acrylate copolymer > 94\%) powders (K-SAM, Kolon Chemical Co., Ltd., Korea) were incorporated into substrates at densities of 0 (Control), 0.25, 0.5, 1.0 , or $2.0 \mathrm{~kg} \cdot \mathrm{m}^{-3}$ (polymer:medium [w/v], dry weight basis), with three replicates per treatment. Organic fertilizers (saudust:manure $(\mathrm{v} / \mathrm{v})=70: 30 \%$, TouJjang, DooHo LandTech., Korea) were added to substrates at $5 \%$ of the total volume to ensure that the 
same quantity was applied to each substrate for healthy plant growth. The depth of all substrates was $20 \mathrm{~cm}$.

Survival rate was calculated by comparing the number of surviving plants versus the number of total plants in each treatment using the following formula. Plants with no green leaves, no new buds were considered to be dead (Pengzhen et al., 2019).

$$
\text { Survival rate }=(\text { surviving plants/ total plants }) \times 100(\%)
$$

The growth parameters observed were plant height, leaf number, leaf length, leaf width of all the plants $(n=9)$ in June and August, respectively. Plant height $(H)$ above the stem base, width at the widest vegetative point of the plant passing through the center (W1), and greatest width perpendicular to W1 (W2) were measured in June and August during the peak growth period. Height and width measurements were used to calculate the growth index (GI).

$$
\text { Growth index }(\mathrm{GI})=[(\mathrm{W} 1+\mathrm{W} 2) / 2+\mathrm{H}] / 2
$$

The relative appearance of the plant was evaluated according to visual quality, which was categorized into five grades: grade 1, severely stressed and completely dried out; grade 2, stressed with less than $50 \%$ of the leaves retaining green pigmentation; grade 3 , mildly stressed with $50 \%$ of the leaves retaining green pigmentation; grade 4 , minor stress with over $50 \%$ of the leaves appearing healthy; and grade 5, unstressed with all leaves appearing healthy (Nagase and Dunnett, 2010). The chlorophyll content of the leaves was measured for 9 leaves per container using a SPAD-502 meter (Minolta Camera Co., Ltd, Osaka, Japan). The total number of flowers per plant was monitored from September to November during the blooming season.

Data were subjected to analysis of variance (ANOVA) with SAS 9.1 software package (SAS version 9.1, SAS Institute, Cary, NC). Post hoc analysis was conducted using Tukey's post-hoc test. Statistical significance was considered when $p$ value was less than 0.05 .

\section{Results}

Compared to $\mathrm{C}_{4} \mathrm{P}_{1}$ substrate, the survival rate of Salvia elegans was reduced to $89 \%$ and $78 \%$ in the $\mathrm{C}_{1} \mathrm{P}_{1}$ and $\mathrm{C}_{1} \mathrm{P}_{4}$ substrates, respectively, under the Control treatment in June. There were no obvious differences in plant survival rate among the three differenet substreate and five hydrophilic polymer treatments in August. The plant height, leaf number, and growth index of Salvia elegans were significantly higher in the $\mathrm{C}_{4} \mathrm{P}_{1}$ and $\mathrm{C}_{1} \mathrm{P}_{1}$ substrates than the $\mathrm{C}_{1} \mathrm{P}_{4}$ substrate in June. There were significant interactions between substrate and hydrophilic polymer, despite leaf length and leaf width (Table 1). This might have occurred because the higher coir dust-based $\mathrm{C}_{4} \mathrm{P}_{1}$ substrate and hydrophilic polymer increased the water-holding capacity available for plant growth in June, when there was less rainfall, resulting in better growth. However, the higher hydrophilic polymer treatments had little significant effect on growth of Salvia elegans in $\mathrm{C}_{4} \mathrm{P}_{1}$ substrate, while a higher hydrophilic polymer level (e.g., $2.0 \mathrm{~kg} \cdot \mathrm{m}^{-3}$ ) produced greater growth index of Salvia elegans under $\mathrm{C}_{1} \mathrm{P}_{1}$ or $\mathrm{C}_{1} \mathrm{P}_{4}$ substrate in August (Table 2). 
Table 1. Survival rate and plant parameters (plant height, leaf number, leaf length, leaf width, and growth index) of Salvia elegans grown in three green roof substrates during the drought period (June)

\begin{tabular}{|c|c|c|c|c|c|c|c|}
\hline Substrate & $\begin{array}{c}\text { Polymer rate } \\
\left(\mathrm{kg} \cdot \mathrm{m}^{-3}\right)\end{array}$ & $\begin{array}{c}\text { Survival rate } \\
(\%)\end{array}$ & \begin{tabular}{|c|}
$\begin{array}{c}\text { Plant height } \\
(\mathrm{cm})\end{array}$ \\
\end{tabular} & $\begin{array}{l}\text { No. of leaves } \\
\text { (per plant) }\end{array}$ & \begin{tabular}{|c|}
$\begin{array}{c}\text { Leaf length } \\
(\mathrm{mm})\end{array}$ \\
\end{tabular} & \begin{tabular}{|c} 
Leaf width \\
$(\mathrm{mm})$
\end{tabular} & $\begin{array}{c}\text { Growth } \\
\text { index }\end{array}$ \\
\hline $\mathrm{C}_{4} \mathrm{P}_{1}^{\mathrm{y}}$ & $\begin{array}{c}\text { Control }^{\mathrm{x}} \\
0.25 \\
0.50 \\
1.00 \\
2.00 \\
\end{array}$ & $\begin{array}{l}100 \mathrm{a} \\
100 \mathrm{a} \\
100 \mathrm{a} \\
100 \mathrm{a} \\
100 \mathrm{a} \\
\end{array}$ & $\begin{array}{l}17.7 \mathrm{a}^{\mathrm{z}} \\
16.6 \mathrm{a} \\
17.6 \mathrm{a} \\
17.2 \mathrm{a} \\
15.5 \mathrm{a} \\
\end{array}$ & $\begin{array}{c}73.7 \mathrm{ab} \\
66.1 \mathrm{~b} \\
86.2 \mathrm{a} \\
82.1 \mathrm{a} \\
76.7 \mathrm{ab} \\
\end{array}$ & $\begin{array}{c}55.7 \mathrm{~b} \\
54.2 \mathrm{~b} \\
58.0 \mathrm{ab} \\
61.6 \mathrm{a} \\
55.4 \mathrm{~b} \\
\end{array}$ & $\begin{array}{l}26.0 \mathrm{~b} \\
25.6 \mathrm{~b} \\
25.0 \mathrm{~b} \\
27.6 \mathrm{a} \\
25.7 \mathrm{~b}\end{array}$ & $\begin{array}{l}17.1 \mathrm{a} \\
16.6 \mathrm{a} \\
17.2 \mathrm{a} \\
16.9 \mathrm{a} \\
15.9 \mathrm{a} \\
\end{array}$ \\
\hline $\mathrm{C}_{1} \mathrm{P}_{1}$ & $\begin{array}{c}\text { Control } \\
0.25 \\
0.50 \\
1.00 \\
2.00 \\
\end{array}$ & $\begin{array}{c}89 \mathrm{a} \\
100 \mathrm{a} \\
100 \mathrm{a} \\
100 \mathrm{a} \\
89 \mathrm{a} \\
\end{array}$ & $\begin{array}{l}17.4 \mathrm{a} \\
15.2 \mathrm{a} \\
15.1 \mathrm{a} \\
16.0 \mathrm{a} \\
15.9 \mathrm{a} \\
\end{array}$ & $\begin{array}{c}61.1 \mathrm{~b} \\
58.2 \mathrm{~b} \\
69.5 \mathrm{ab} \\
67.8 \mathrm{ab} \\
73.8 \mathrm{a} \\
\end{array}$ & $\begin{array}{l}59.0 \mathrm{a} \\
53.9 \mathrm{a} \\
54.6 \mathrm{a} \\
59.2 \mathrm{a} \\
61.5 \mathrm{a} \\
\end{array}$ & $\begin{array}{l}23.1 \mathrm{a} \\
24.5 \mathrm{a} \\
23.0 \mathrm{a} \\
24.4 \mathrm{a} \\
26.3 \mathrm{a} \\
\end{array}$ & $\begin{array}{l}16.2 \mathrm{a} \\
14.8 \mathrm{a} \\
15.8 \mathrm{a} \\
15.7 \mathrm{a} \\
15.5 \mathrm{a} \\
\end{array}$ \\
\hline $\mathrm{C}_{1} \mathrm{P}_{4}$ & $\begin{array}{c}\text { Control } \\
0.25 \\
0.50 \\
1.00 \\
2.00\end{array}$ & $\begin{array}{c}78 \mathrm{a} \\
100 \mathrm{a} \\
100 \mathrm{a} \\
100 \mathrm{a} \\
100 \mathrm{a}\end{array}$ & $\begin{array}{l}14.5 \mathrm{a} \\
14.1 \mathrm{a} \\
13.8 \mathrm{a} \\
13.4 \mathrm{a} \\
15.0 \mathrm{a}\end{array}$ & $\begin{array}{l}73.2 \mathrm{a} \\
70.7 \mathrm{a} \\
66.6 \mathrm{a} \\
68.7 \mathrm{a} \\
73.0 \mathrm{a}\end{array}$ & $\begin{array}{c}50.3 \mathrm{~b} \\
49.6 \mathrm{~b} \\
48.4 \mathrm{~b} \\
54.2 \mathrm{ab} \\
57.4 \mathrm{a}\end{array}$ & $\begin{array}{c}20.8 \mathrm{~b} \\
25.2 \mathrm{ab} \\
21.7 \mathrm{ab} \\
21.4 \mathrm{ab} \\
24.9 \mathrm{a}\end{array}$ & $\begin{array}{c}14.5 \mathrm{ab} \\
14.0 \mathrm{bc} \\
13.4 \mathrm{~b} \\
13.8 \mathrm{bc} \\
15.4 \mathrm{a}\end{array}$ \\
\hline Significance & $\begin{array}{c}\text { Substrate } \\
\text { Polymer rate } \\
\text { Interaction }\end{array}$ & $\begin{array}{l}\text { NS } \\
\text { NS } \\
\text { NS }\end{array}$ & $\begin{array}{l}* * * \\
\text { NS } \\
\text { NS }\end{array}$ & $\begin{array}{c}* * * \\
* \\
*\end{array}$ & $\begin{array}{c}* * \\
* \\
\mathrm{NS}\end{array}$ & $\begin{array}{l}* * \\
\text { NS } \\
\text { NS }\end{array}$ & $\begin{array}{l}* * * \\
* * \\
* * *\end{array}$ \\
\hline
\end{tabular}

${ }^{\mathrm{z}}$ Means followed by the same letters in columns are not significantly different according to Turkey's post hoc test at $p \leq 0.05$ level $(\mathrm{n}=9)$. ***, **, *: $p<0.001, p<0.01, p<0.05$, respectively.

NS: not significant. ${ }^{y}$ Substrate: $\mathrm{C}_{4} \mathrm{P}_{1}$ : coir $80 \%$, perlite $20 \% ; \mathrm{C}_{1} \mathrm{P}_{1}$ : coir $50 \%$, perlite $50 \% ; \mathrm{C}_{1} \mathrm{P}_{4}$ : coir $20 \%$, perlite $80 \%$ (\% by volume). ${ }^{\mathrm{x}}$ Hydrophilic polymer rate: 0 (referred as to Control), 0.25, 0.5, 1.0, and $2.0 \mathrm{~kg} \cdot \mathrm{m}^{-3}$ [polymer: medium (w/v), dry weight basis]

Table 2. Survival rate and plant parameters (plant height, leaf number, leaf length, leaf width, and growth index) of Salvia elegans grown in three green roof substrates during the rainy period (August)

\begin{tabular}{c|c|c|c|c|c|c|c}
\hline Substrate & $\begin{array}{c}\text { Polymer rate } \\
\left(\mathbf{k g} \cdot \mathbf{m}^{-3}\right)\end{array}$ & $\begin{array}{c}\text { Survival rate } \\
(\boldsymbol{\%})\end{array}$ & $\begin{array}{c}\text { Plant height } \\
(\mathbf{c m})\end{array}$ & $\begin{array}{c}\text { No. of leaves } \\
(\text { per } \mathbf{p l a n t})\end{array}$ & $\begin{array}{c}\text { Leaf length } \\
(\mathbf{m m})\end{array}$ & $\begin{array}{c}\text { Leaf width } \\
(\mathbf{m m})\end{array}$ & $\begin{array}{c}\text { Growth } \\
\text { index }\end{array}$ \\
\hline \multirow{5}{*}{$\mathrm{C}_{4} \mathrm{P}_{1}{ }^{\mathrm{y}}$} & $\mathrm{Control}^{\mathrm{x}}$ & $100 \mathrm{a}$ & $30.1 \mathrm{a}^{\mathrm{z}}$ & $76.9 \mathrm{ab}$ & $69.6 \mathrm{a}$ & $28.3 \mathrm{a}$ & $27.1 \mathrm{a}$ \\
& 0.25 & $100 \mathrm{a}$ & $27.0 \mathrm{a}$ & $75.0 \mathrm{ab}$ & $67.8 \mathrm{a}$ & $27.4 \mathrm{a}$ & $25.6 \mathrm{ab}$ \\
& 0.50 & $100 \mathrm{a}$ & $30.3 \mathrm{a}$ & $94.1 \mathrm{a}$ & $72.0 \mathrm{a}$ & $29.4 \mathrm{a}$ & $27.4 \mathrm{a}$ \\
& 1.00 & $100 \mathrm{a}$ & $28.7 \mathrm{a}$ & $92.9 \mathrm{a}$ & $71.4 \mathrm{a}$ & $28.4 \mathrm{a}$ & $26.7 \mathrm{a}$ \\
& 2.00 & $100 \mathrm{a}$ & $25.6 \mathrm{a}$ & $65.3 \mathrm{~b}$ & $62.6 \mathrm{a}$ & $26.0 \mathrm{a}$ & $23.7 \mathrm{~b}$ \\
\hline \multirow{5}{*}{$\mathrm{C}_{1} \mathrm{P}_{1}$} & Control & $89 \mathrm{a}$ & $26.8 \mathrm{a}$ & $65.2 \mathrm{c}$ & $65.7 \mathrm{a}$ & $27.0 \mathrm{a}$ & $24.1 \mathrm{a}$ \\
& 0.25 & $100 \mathrm{a}$ & $25.2 \mathrm{a}$ & $57.8 \mathrm{c}$ & $64.0 \mathrm{a}$ & $25.2 \mathrm{a}$ & $23.2 \mathrm{a}$ \\
& 0.50 & $100 \mathrm{a}$ & $24.5 \mathrm{a}$ & $91.0 \mathrm{ac}$ & $69.5 \mathrm{a}$ & $27.7 \mathrm{a}$ & $24.7 \mathrm{a}$ \\
& 1.00 & $100 \mathrm{a}$ & $27.7 \mathrm{a}$ & $92.2 \mathrm{a}$ & $73.2 \mathrm{a}$ & $31.0 \mathrm{a}$ & $26.0 \mathrm{a}$ \\
& 2.00 & $89 \mathrm{a}$ & $27.2 \mathrm{a}$ & $69.8 \mathrm{bc}$ & $74.2 \mathrm{a}$ & $29.7 \mathrm{a}$ & $24.9 \mathrm{a}$ \\
\hline \multirow{5}{*}{$\mathrm{C}_{1} \mathrm{P}_{4}$} & Control & $89 \mathrm{a}$ & $28.2 \mathrm{a}$ & $93.9 \mathrm{a}$ & $67.5 \mathrm{~b}$ & $27.9 \mathrm{~b}$ & $26.9 \mathrm{ab}$ \\
& 0.25 & $100 \mathrm{a}$ & $27.8 \mathrm{a}$ & $103.1 \mathrm{a}$ & $71.0 \mathrm{~b}$ & $29.0 \mathrm{ab}$ & $26.2 \mathrm{ab}$ \\
& 0.50 & $100 \mathrm{a}$ & $26.5 \mathrm{a}$ & $84.1 \mathrm{a}$ & $72.8 \mathrm{ab}$ & $30.1 \mathrm{ab}$ & $25.5 \mathrm{~b}$ \\
& 1.00 & $89 \mathrm{a}$ & $26.7 \mathrm{a}$ & $89.2 \mathrm{a}$ & $73.3 \mathrm{ab}$ & $30.0 \mathrm{ab}$ & $27.1 \mathrm{ab}$ \\
& 2.00 & $100 \mathrm{a}$ & $28.6 \mathrm{a}$ & $99.2 \mathrm{a}$ & $78.9 \mathrm{a}$ & $31.3 \mathrm{a}$ & $28.4 \mathrm{a}$ \\
\hline \multirow{3}{*}{ Significance } & Substrate & $\mathrm{NS}$ & $*$ & $*$ & $\mathrm{NS}$ & $\mathrm{NS}$ & $* * *$ \\
& Polymer rate & $\mathrm{NS}$ & $\mathrm{NS}$ & $\mathrm{NS}$ & $\mathrm{NS}$ & $\mathrm{NS}$ & $\mathrm{NS}$ \\
& Interaction & $\mathrm{NS}$ & $\mathrm{NS}$ & $\mathrm{NS}$ & $\mathrm{NS}$ & $\mathrm{NS}$ & $*$ \\
\hline
\end{tabular}

${ }^{z}$ Means followed by the same letters in columns are not significantly different according to Turkey's post hoc test at $p \leq 0.05$ level $(\mathrm{n}=9)$. ***, **, *: $p<0.001, p<0.01, p<0.05$, respectively.

NS: not significant. ${ }^{\mathrm{y}}$ Substrate: $\mathrm{C}_{4} \mathrm{P}_{1}$ : coir $80 \%$, perlite $20 \% ; \mathrm{C}_{1} \mathrm{P}_{1}$ : coir $50 \%$, perlite $50 \% ; \mathrm{C}_{1} \mathrm{P}_{4}$ : coir $20 \%$, perlite $80 \%$ (\% by volume). ${ }^{x}$ Hydrophilic polymer rate: 0 (referred as to Control), 0.25, 0.5, 1.0, and $2.0 \mathrm{~kg} \cdot \mathrm{m}^{-3}$ [polymer: medium (w/v), dry weight basis] 
In $\mathrm{C}_{4} \mathrm{P}_{1}$ and $\mathrm{C}_{1} \mathrm{P}_{1}$ substrates with $2.0 \mathrm{~kg} \cdot \mathrm{m}^{-3}$ of hydrophilic polymer, visual quality was at least 1.7 -fold greater than in $\mathrm{C}_{1} \mathrm{P}_{4}$ substrates. Higher visual quality of Salvia elegans was associated with higher hydrophilic polymer content in the three substrates under drought stress in June, especially under the condition of $2.0 \mathrm{~kg} \cdot \mathrm{m}^{-3}$. This finding highlights the effectiveness of hydrophilic polymer as a soil conditioner that can hold water in substrates during dry periods. However, in August, the hydrophilic polymer treatment caused decreased gradually under the $\mathrm{C}_{4} \mathrm{P}_{1}$ and $\mathrm{C}_{1} \mathrm{P}_{1}$, but not in $\mathrm{C}_{1} \mathrm{P}_{4}$ substrates.

Chlorophyll contents were lower in the $\mathrm{C}_{4} \mathrm{P}_{1}$ substrate compared with other treatments, and the addition of hydrophilic polymer tended to decrease chlorophyll contents in June. There was no significant interaction observed between substrate and hydrophilic polymer rate on chlorophyll contents, while significantly higher chlorophyll contents in substrates $\mathrm{C}_{1} \mathrm{P}_{4}$ and $\mathrm{C}_{1} \mathrm{P}_{1}$ than in the $\mathrm{C}_{4} \mathrm{P}_{1}$ substrate. Overall, chlorophyll contents reduction was present in all treatments in August compared to June, which might have occurred because Salvia elegans experienced waterlogging in the high water content substrate (Table 3).

Table 3. Visual quality and chlorophyll contents of Salvia elegans grown in different green roof substrates during the drought and the rainy periods

\begin{tabular}{|c|c|c|c|c|c|}
\hline \multirow[b]{2}{*}{ Substrate } & \multirow{2}{*}{$\begin{array}{c}\text { Polymer rate } \\
\left(\mathbf{k g} \cdot \mathbf{m}^{-3}\right)\end{array}$} & \multicolumn{2}{|r|}{ June } & \multicolumn{2}{|r|}{ August } \\
\hline & & $\begin{array}{c}\text { Visual quality } \\
(5 \text { grade })\end{array}$ & $\begin{array}{c}\text { Chlorophyll contents } \\
\text { (SPAD value) }\end{array}$ & \begin{tabular}{|c|}
$\begin{array}{c}\text { Visual quality } \\
\text { (5 grade) }\end{array}$ \\
\end{tabular} & $\begin{array}{c}\text { Chlorophyll contents } \\
\text { (SPAD value) }\end{array}$ \\
\hline \multirow{5}{*}{$\mathrm{C}_{4} \mathrm{P}_{1}^{\mathrm{y}}$} & Control $^{\mathrm{x}}$ & $1.2 \mathrm{~b}^{\mathrm{x}}$ & $30.02 \mathrm{ab}$ & $4.6 \mathrm{a}$ & $21.49 \mathrm{ab}$ \\
\hline & 0.25 & $1.2 \mathrm{~b}$ & $28.47 \mathrm{ab}$ & $4.6 \mathrm{a}$ & $21.90 \mathrm{ab}$ \\
\hline & 0.50 & $1.7 \mathrm{~b}$ & $31.13 \mathrm{ab}$ & $4.6 \mathrm{a}$ & $20.30 \mathrm{~b}$ \\
\hline & 1.00 & $1.7 \mathrm{~b}$ & $31.83 \mathrm{a}$ & $4.4 \mathrm{ab}$ & $22.99 \mathrm{a}$ \\
\hline & 2.00 & $3.4 \mathrm{a}$ & $27.94 \mathrm{~b}$ & $4.0 \mathrm{a}$ & $23.42 \mathrm{a}$ \\
\hline \multirow{5}{*}{$\mathrm{C}_{1} \mathrm{P}_{1}$} & Control & $1.0 \mathrm{~b}$ & $38.26 \mathrm{a}$ & $4.4 \mathrm{a}$ & $23.48 \mathrm{~b}$ \\
\hline & 0.25 & $1.0 \mathrm{~b}$ & $33.39 \mathrm{ab}$ & $4.3 \mathrm{a}$ & $24.43 \mathrm{ab}$ \\
\hline & 0.50 & $1.0 \mathrm{~b}$ & $37.04 \mathrm{ab}$ & $4.1 \mathrm{a}$ & $25.48 \mathrm{ab}$ \\
\hline & 1.00 & $1.6 \mathrm{~b}$ & $36.49 \mathrm{ab}$ & $3.9 \mathrm{a}$ & $25.66 \mathrm{a}$ \\
\hline & 2.00 & $2.9 \mathrm{a}$ & $31.72 \mathrm{~b}$ & $4.0 \mathrm{a}$ & $26.18 \mathrm{a}$ \\
\hline \multirow{5}{*}{$\mathrm{C}_{1} \mathrm{P}_{4}$} & Control & $1.0 \mathrm{~b}$ & $35.84 \mathrm{a}$ & $4.1 \mathrm{~b}$ & $25.54 \mathrm{a}$ \\
\hline & 0.25 & $1.0 \mathrm{~b}$ & $36.41 \mathrm{a}$ & $4.9 \mathrm{a}$ & $23.66 \mathrm{a}$ \\
\hline & 0.50 & $1.0 \mathrm{~b}$ & $34.33 \mathrm{a}$ & $4.6 \mathrm{a}$ & $24.12 \mathrm{a}$ \\
\hline & 1.00 & $1.0 \mathrm{~b}$ & $35.96 \mathrm{a}$ & $5.0 \mathrm{a}$ & $23.80 \mathrm{a}$ \\
\hline & 2.00 & $1.4 \mathrm{a}$ & $34.40 \mathrm{a}$ & $5.0 \mathrm{a}$ & $24.76 \mathrm{a}$ \\
\hline \multirow{3}{*}{ Significance } & Substrate & $* * *$ & $* * *$ & $* * *$ & $* * *$ \\
\hline & Polymer rate & $* * *$ & $*$ & NS & $*$ \\
\hline & Interaction & $* * *$ & NS & * & $*$ \\
\hline
\end{tabular}

${ }^{z}$ Means followed by the same letters in columns are not significantly different according to Turkey's post hoc test at $p \leq 0.05$ level $(\mathrm{n}=9)$. ***, **, *: $p<0.001, p<0.01, p<0.05$, respectively.

NS: not significant. ${ }^{y}$ Substrate: $\mathrm{C}_{4} \mathrm{P}_{1}$ : coir $80 \%$, perlite $20 \% ; \mathrm{C}_{1} \mathrm{P}_{1}$ : coir $50 \%$, perlite $50 \% ; \mathrm{C}_{1} \mathrm{P}_{4}$ : coir $20 \%$, perlite $80 \%$ (\% by volume). ${ }^{\mathrm{x}}$ Hydrophilic polymer rate: 0 (referred as to Control), 0.25, 0.5, 1.0, and $2.0 \mathrm{~kg} \cdot \mathrm{m}^{-3}$ [polymer: medium (w/v), dry weight basis]

In our study, Salvia elegans bloomed from the middle of September through the middle of November, after first frost. The peak blooming period was from early October until the first frost. There was a significant difference in the total number of inflorescences per plant among the three substrates. The mean number of inflorescences 
grown in $\mathrm{C}_{1} \mathrm{P}_{4}$ substrate was 1.78 - folder higher than those grown in $\mathrm{C}_{4} \mathrm{P}_{1}$ and 1.91-fold higher than those grown in $\mathrm{C}_{1} \mathrm{P}_{1}$ substrate. Hydrophilic polymer increased the total number of inflorescences in $\mathrm{C}_{1} \mathrm{P}_{4}$ substrate, especially under the $2.0 \mathrm{~kg} \cdot \mathrm{m}^{-3}$ treatment, compared to the other hydrophilic polymer treatments or the Control treatment (Fig. 2).

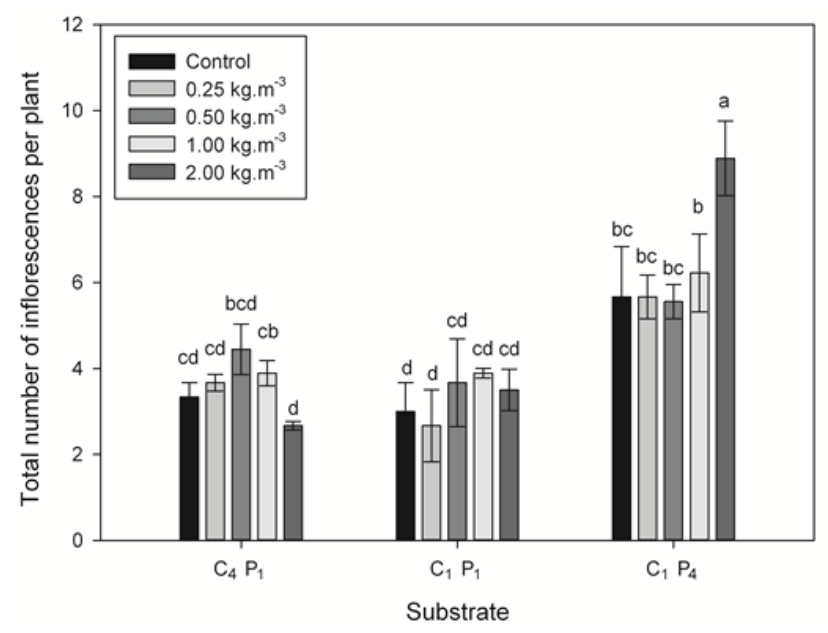

Figure 2. Total number of inflorescences of Salvia elegans per plant of the three different green roof substrates $\left[C_{4} P_{1}\right.$ : coir $80 \%$, perlite $20 \%$; $C_{1} P_{1}$ : coir $50 \%$, perlite $50 \%$; $C_{1} P_{4}$ : coir $20 \%$, perlite $80 \%$ (\% by vol.)] amended with five contents of hydrophilic polymer, including 0 (referred as Control), 0.25, 0.5, 1.0, and $2.0 \mathrm{~kg} \cdot \mathrm{m}^{-3}$ [polymer: medium (w/v), dry weight basis]. Different letters indicate significant differences by Turkey's post hoc test at $p \leq 0.05$ level. Data represent mean $\pm S E(n=9)$

\section{Discussion}

Higher survival of Salvia elegans was associated with higher hydrophilic polymer content in the three substrates under drought stress. This finding is consistent with other studies, in which the addition of hydrophilic polymer prolonged the survival of seedlings compared to the Control (no hydrophilic polymer) treatment. In addition, hydrophilic polymer can be used to improve the transplant success of seedlings (Thomas, 2008). The addition of hydrogels slowed soil moisture loss and delayed the wilting time of seedlings by 4 to 5 days (Akhter et al., 2004). Greater hydrophilic polymer addition also improved the water-holding properties of substrate and delayed the permanent wilting point (Patil et al., 2011). Therefore, application of hydrophilic polymer is an important remedy for perlite-based substrate, as it assists growth by increasing water retention and availability to plant in dry periods. Meanwhile, frequent rainfall during the summer rainy season in August might have resulted in frequent wetting of the substrates, thus leading to waterlogging and reduced effectiveness of the hydrophilic polymer. For this reason, a further increase in coir dust-based substrate had no or minimal effect on growth of Salvia elegans in August, during the rainy season.

The higher hydrophilic polymer was inefficient for plants grown in $\mathrm{C}_{4} \mathrm{P}_{1}$ and $\mathrm{C}_{1} \mathrm{P}_{1}$ substrates in the rainy season. These results confirmed that the growth of Salvia elegans was affected by the composition of the substrate more than the level of hydrophilic polymer during the drought period. In addition, the substrate amended with a high amount of coir dust might have aided with water holding-capacity, thus maintaining the structural integrity of plants, as coir dust has a high surface area of $4 \mathrm{~m}^{2} / \mathrm{g}$ (Bilderback 
et al., 2005). A previous study found that shoot and root growth of Gerbera were greater under coir-based substrate than rockwool (Cho et al., 2006). The growth of highbush blueberry (Vaccinium Sp.) under various amounts of substrates for container production and found that total plant dry weight was greater under higher contents of coir substrate (Kingston et al., 2017). However, another study did not recommend high level of coir dust in green roof substrate (Olle et al., 2012), and the substrate containing 10\% organic matter was optimal for the growth of four herbaceous plants under dry and wet conditions on green roofs (Nagase and Dunnett, 2011). Increased organic matter, such as coir dust or peat-moss, can result in lush growth that might suffer damage under drought stress or frequent rainfall, resulting in frequent drying and wetting cycles.

The chlorophyll meter is a simple tool to measure the relative chlorophyll content or greenness; thus, it is an efficient indicator of stress in plants (Netto et al., 2005). The change in chlorophyll content of plants under water stress depends on the rate of stress and plant species (Hassanzadeh et al., 2009). In the present study, higher chlorophyll content was associated with low water content of the substrate under severe drought stress in June. This finding can be explained by reductions in relative water content and leaf water potential under mild water stress, which can change the color of the leaf to dark green compared with the color of the plant in a substrate with a higher water content (Marenco et al., 2009).

Salvia species prefers moist, well-drained, fertile loam or sandy loam soils (Silva et al., 2018). Several studies have found that drought reduces inflorescence numbers (Razmjoo et al., 2008; Beya-Marshall et al., 2018). Hydrophilic polymer supplementation increased substrate water content, and thereby prevented drought in perlite-based $\mathrm{C}_{1} \mathrm{P}_{4}$ substrate, while the intensity of rainfall in August might have caused waterlogging in $\mathrm{C}_{4} \mathrm{P}_{1}$ and $\mathrm{C}_{1} \mathrm{P}_{1}$ substrates, reducing the number of inflorescences. Hydrophilic polymer treatments were positively associated with number of inflorescences of Salvia elegans in the three substrates. However, $\mathrm{C}_{4} \mathrm{P}_{1}$ and $\mathrm{C}_{1} \mathrm{P}_{1}$ substrates with high coir dust matter are not recommended for Salvia elegans because the plants showed low growth in the rainy season and poor ornamental quality at peak flower time with these substrates. Therefore, it is feasible to use hydrophilic polymer in inorganic-based substrate to diversify the variety of plants used by increasing substrate water content on green roofs.

\section{Conclusions}

The growth of Salvia elegans was the greatest using $80 \%$ and $20 \%$ of coir dust and perlite in June, and $20 \%$ and $80 \%$ of coir dust and perlite in August after the rainy season. The survival rate and visual quality of Salvia elegans were positively associated with hydrophilic polymer content in three different substrates. However, 50-80\% coir dust in substrates is not recommended for Salvia elegans because the plants showed low growth during the rainy season and poor ornamental quality at peak flower time with these substrates. Overall, $80 \%$ perlite-based substrate amended with a hydrophilic polymer level $>1.0 \mathrm{~kg} \cdot \mathrm{m}^{-3}$ may be considered as the optimal substrate compared to the $50-80 \%$ coir dust based substrate in the dry as well as rainy season on green roofs. Therefore, it is feasible to use hydrophilic polymers in perlite-based substrates to increase substrate water content in diverse plants growing on green roofs. Further studies warrant to determine the effects of substrates with higher rates of hydrophilic polymer in various plants on green roof for a long-term. 
Acknowledgements. This paper was supported by Konkuk University in 2018.

\section{REFERENCES}

[1] Akhter, J., Mahmood, K., Malik, K. A., Mardan, A., Ahmad, M., Iqbal, M. M. (2004): Effects of hydrogel amendment on water storage of sandy loam and loam soils and seedling growth of barley, wheat and chickpea. - Plant Soil Environ. 50: 463-469.

[2] Apostol, K. G., Jacobs, D. F., Dumroese, R. K. (2009): Root desiccation and drought stress responses of bareroot Quercus rubra seedlings treated with a hydrophilic polymer root dip. - Plant Soil 315: 229-240.

[3] Berndtsson, J. C. (2010): Green roof performance towards management of runoff water quantity and quality: a review. - Ecol. Eng. 26: 351-360.

[4] Beya-Marshall, V., Herra, J., Fichet, T., Trentacoste, E. R., Kremer, C. (2018): The effect of water status on productive and flowering variables in young "Arbequina' olive trees under limited irrigation water availability in a semiarid region of Chile. - Hortic. Environ. Biote. 59: 815-826.

[5] Bilderback, T. E., Warren, S. L., Owen, J. S., Albano, J. P. (2005): Healthy substrates need physicals too!. - HortTechnology 15: 747-751.

[6] Castleton, H. F., Stovin, V., Beck, S. B. M., Davison, J. B. (2010): Green roofs; building energy savings and the potential for retrofit. - Energy Buildings 42: 1582-1591.

[7] Cho, M. S., Park, Y. Y., Jun, H. J., Chung, J. B. (2006): Growth of Gerbera in mixtures of coir dust and perlite. - Hortic. Environ. Biotechnol. 47: 211-216.

[8] Cuevas, E., Espino, J., Marques, I., Scopece, G. (2018): Reproductive isolation between Salvia elegans and $S$. fulgens, two hummingbird-pollinated sympatric sages. - Plant Biology 20(6): 1075-1082.

[9] Farrell, C., Ang, X. Q., Rayner, J. P. (2013): Water-retention additives increase plant available water in green roof substrates. - Ecol. Eng. 52: 112-118.

[10] Getter, K. L., Rowe, D. B. (2006): The role of extensive green roofs in sustainable development. - HortScience 41: 1276-1285.

[11] Getter, K. L., Rowe, D. B., Robertson, G. P., Cregg, B. M., Andresen, J. A. (2009): Carbon sequestration potential of extensive green roofs. - Environ. Sci. Technol. 43(19): 7564-7570.

[12] González-Cortazar, M., Maldonado-Abarca, A. M., Jiménez-Ferrer, E., Marquina, S., Ventura-Zapata, E., Zamilpa, A., Tortoriello, J., Herrera-Ruiz, M. (2013): Isosakuranetin5-O-rutinoside: A new flavanone with antidepressant activity isolated from Salvia elegans Vahl. - Molecules 18(11): 13260-13270.

[13] Handreck, K. M., Black, N. D. (2010): Growing media for ornamental plants and turf. 4th (ed.) University of New South Wales Press, Radwick, NSW.

[14] Hassanzadeh, M., Ebadi, A., Panahyane, K. M., Eshghi, A. G., Jamaatiesomarin, S. H., Saeidi, M., Zabihie, M. R. (2009): Evaluation of drought stress on relative water content and chlorophyll content of Sesame (Sesamum indicum L.) genotypes at early flowering stage. - Res. J. Environ. Sci. 3: 345-350.

[15] Hüttermann, A., Orikiriza, L. J., Agaba, H. (2009): Application of superabsorbent polymers for improving the ecological chemistry of degraded or polluted lands. - Clean Soil Air Water 37: 517-526.

[16] Kingston, P. H., Scagel, C. F., Dryla, D. R., Strik, B. (2017): Suitability of sphagnum moss, coir, and douglas fir bark as soilless substrate for container production of highbush blueberry. - HortScience 52: 1692-1699.

[17] Krawczyk, A., Domagala-Swiatkiewicz, I., Lis-Krzyscin, A., Daraz, M. (2017): Waste silica as a valuable component of extensive green-roof substrates. - Pol. J. Enviro. Stud. 26(2): 643-653. 
[18] Marenco, R. A., Antenzana, V. S. A., Nascimento, H. C. S. (2009): Relationship between specific leaf area, leaf thickness, leaf water content and SPAD-502 readings in six Amazonian tree species. - Photosynthetica 47: 184-190.

[19] Nagase, A., Dunnett, N. (2010): Drought tolerance in different vegetation types for extensive green roofs: effects of watering and diversity. - Landscape Urban Plan. 97: 318-327.

[20] Nagase, A., Dunnett, N. (2011): The relationship between percentage of organic matter in substrate and plant growth in extensive green roofs. - Landscape Urban Plan. 103: 230236.

[21] Netto, A. T., Campostrini, E., Oliveira, J. G., Bressan, S. R. E. (2005): Photosynthetic pigments, nitrogen, chlorophyll a fluorescence and SPAD-502 readings in coffee leaves. - Sci. Hortic. 104: 199-209.

[22] Obnerndorfer, E., Lundholm, J., Bass, B., Coffman, R. R., Doshi, H., Dunnett, N., Gaffin, S., Köhler, M., Liu, K. K. Y., Rowe, B. (2007): Green roofs as urban ecosystems: ecological structures, functions, and services. - Bioscience 57(10): 823-833.

[23] Olle, M., Ngouajio, M., Siomos, A. (2012): Vegetable quality and productivity as influenced by growing medium: a review. - Zemdirbyste 99: 399-408.

[24] Orikiriza, L. J. B., Agaba, H., Eilu, G., Kabasa, J. D., Worbes, M., Hüttermann, A. (2013): Effects of hydrogels on tree seedling performance in temperate soils before and after water stress. - J. Environ. Prot. 4(7): 713-721.

[25] Papafotiou, M., Pergialioti, N., Tassoula, L., Massas, I., Kargas, G. (2013): Growth of native aromatic xerophytes in an extensive Mediterranean green roof as affected by substrate type and depth and irrigation frequency. - HortScience 48: 1327-1333.

[26] Park, K. W. (2007): Herb \& Aromatherapy. - Sunjinmunhwasa, Seoul.

[27] Patil, S. V., Salunke, B. K., Patill, C. D., Salunkhe, R. B. (2011): Studies on amendment of different biopolymers in sandy loam and their effect on germination, seedling growth of Gossypium herbaceum L. - Appl. Biochem. Biotechnol. 163: 780-791.

[28] Pengzhen, D., Stefan, K., Arndt, C. F. (2019): Is plant survival on green roofs related to their drought response, water use or climate of origin? - Science of the Total Environment 667: 25-32.

[29] Razmjoo, K., Heydarizadeh, P., Sabzalian, M. R. (2008): Effect of salinity and drought stresses on growth parameters and essential oil content of Matricaria chamomile. - Int. J. Agric. Biol. 10: 451-454.

[30] Rowe, D. B. (2011): Green roofs as a means of pollution abatement. - Environ. Pollut. 159: 2100-2110.

[31] Silva, H., Arrigada, C., Campos-Saez, S., Baginsky, C., Castellaro-Galdames, G., Morales-Salina, L. (2018): Effect of sowing data and water availability on growth of plants of chia (Salvia hispanica L.) established in Chile. - PLoS One 13(9): e0203116.

[32] Thomas, D. S. (2008): Hydrogel applied to the root plug of subtropical eucalypt seedlings halves transplant death following planting. - Forest Ecol. Manage. 255(3-4): 1305-1314.

[33] Xu, H., Yoon, Y. H., Choi, E. Y., Kang, H. K., Ju, J. H. (2014): Combination effects of the use of hydrophilic polymer for green roof substrate and rainy season condition on growth and biomass partitioning of Aster koraiensis. - J. Food Agric. Environ. 12: 11771181.

[34] Xue, M., Farrell, C. (2020): Use of organic wastes to create lightweight green roof substrates with increased plant-avilable water. - Urban Forestry \& Urban Greening 48: 126569.

[35] Young, T. M., Cameron, D. D., Phoenix, G. K. (2017): Increasing green roof plant drought tolerance through substrate modification and the use of water retention gels. Urban Water J. 14: 551-560. 